\title{
Congress announcement: ANATOMIA CLINICA, Madrid, Spain, 2019, June 24-26
}

(c) Springer-Verlag France SAS, part of Springer Nature 2019

http://www.eaca2019.com

ANATOMIA CLINICA will be the Joint Congress of the 15th Congress of the European Association of Clinical Anatomists (EACA) and the 11th International Symposium of Clinical and Applied Anatomy (ISCAA).

The invited societies are the Japanese Research Society of Clinical Anatomy (JRSCA), the Mexican Anatomical Society (SMA) and the Spanish Anatomical Society (SAE).

This will be an important international meeting in the fields of clinical and applied anatomy, and translational research in anatomical sciences.
This meeting will be held in Madrid, Spain, on June 24th-25th and 26th, 2019. SAVE THE DATES NOW!

On behalf of the President of the Congress, PR J Sanudo, and Vice-President, PR T Vasquez, and of the Presidents of the Scientific Committee, F Duparc (France) and M Konschake (Austria), you are invited to save the dates and submit your abstract(s) on the website:

https://eaca2019.com/index.php/abstract.

Surgical and Radiologic Anatomy will be the official organ of the journal, and the accepted abstracts for the Congress will be published in this journal. 